EMILIA ŚMIECHOWSKA-PETROVSKIJ

Faculty of Education

Cardinal Stefan Wyszyński University

Warsaw
Forum Pedagogiczne

$2017 / 2$

Wpłynęło: 21.04.2017

Zatwierdzono do druku: 12.05.2017

DOI: 10.21697/fp.2017.2.22

\title{
THE STIGMATIZING AND STEREOTYPING PEOPLE WITH BLINDNESS. THE OPPOSITE TENDENCIES ${ }^{1}$
}

\begin{abstract}
The aim of the paper is to present aspects of stigmatizing and stereotyping the visually impaired people in the light of social stigma theory of Erving Goffman. Also discussed are the tendencies contrary to the phenomena of social stigma as well as the creation of simplified cognitive schemes related to people with blindness. These tendencies are for example: revision of common speech and cultural discourse to not to consolidate false image of people with blindness. At the end of the paper there are also presented practical tools and materials which can be useful in pedagogical practice.
\end{abstract}

Keywords: blindness, blind person, stigma, stereotype.

\section{Introduction}

Nowadays stigmatizing and stereotyping are very productive categories while describing negative social facts concerning different communities, including people with disabilities. However, in relation to blind people the aspects of stigma and stigmatizing are rarely used (more often the related phenomenon - stereotype - is analyzed). But, after all, both in the theoretical studies concerning the aspect of stigma as well as in the empirical ones, disabled people are almost always mentioned as subordinate to this aspect (e.g. Goffman 2005; Biernat, Dovidio 2008; Czykwin 2007). These ones are quite often experimental and examine the reactions and attitude towards people affected by a stigma, the blind are also included in the stigma group (e.g. Fine, Ash 1988; Rush 1998; Menec, Perry 1998).

1 Artykuł jest przekształconą i nieco poszerzoną wersją tekstu, który został opublikowany w języku polskim pt.: Aspekty stygmatyzacji i stereotypizacji osób niewidomych oraz tendencje przeciwstawne (2014). W: Od stereotypu do wykluczenia. Fidelus A. (red.). Warszawa: Wydawnictwo Naukowe UKSW. 
The aim of the article is to introduce the aspects of stigmatizing and stereotyping the blind people and to present opposing tendencies, possible to observe these days. It is necessary to properly use these two different categories while describing their social functions, as well as to design and implement solutions resulting in inclusion and normalization of the lives of blind people.

\section{The stigma of a blind person}

In a classic discourse on the subject of stigma: Stigma: Notes on the Management of Spoiled Identity Erving Goffman concludes that stigmatized people are the ones having a significantly discrediting attribute, and who are perceived as defective ones because of it (Goffman 2005, p. 32). People classified as stigmatized are people with certain physical damages, inncluding such disabilities as blindness. This group includes also the people with defects of character or characterized by a tribal stigma - concerned with race, nationality or religion (Goffman 2005, p. 34). Therefore, the beginning of the process of stigmatizing is the presence of a sign, a stigma which will result in perceiving such individual as deviated from the norm and devalued because of it. However, an individual awareness that some person has a certain feature is not sufficient to create a stigma. The phenomenon of stigma is activated when a notice attribute is treated as crucial and discrediting a given person in all situations. According to this definition of stigma mental disorders, certain race, drug abuse or physical/sensory restraints (such as loss of sight) may be a basis for stigma.

Despite the fact that Erving Goffman's attitude towards stigma is characterized by perceiving it as a micro-level phenomenon - present in everyday life relations between stigmatized and not stigmatized persons, and on their auto-perception level, as well as in dealing with tensions arising from social interactions - he also indicates additional components and consequences of the phenomenon:

- stigma disqualifies individuals from an undisturbed participation in social life; it separates and isolates;

- its results are updated during social interactions;

- stigma is not a static but a dynamic category; one can acquire and get rid of acertain stigma (Pescolido, Martin 2007, p. 308-309).

In relation to blind people the categories of stigma and stigmatizing are being updated on two different levels.

The first of them is the reaction to visual otherness of some blind people. It is connected with: possible facial deformation, blindism characteristic for blind children (stereotyped behaviors, such as swaying back and forth and to the sides, spinning around, shacking head or arms or pressing eyeballs) or incorrect physical movement. The scientists have proved that reactions to uncharacteristic physical features, body deformations (such as facial defects, visible hallmarks of the blindness) are usually similar. They take the form of strong emotional stimulation, 
significant discomfort or fear (Stangor, Crandall 2008, p. 87). Therefore, they contribute to the avoidance of contact and may shape negative attitudes towards people bearing such features.

The other level is identifying the blind by attributes, such as white cane, a guide dog or dark glasses. In social reception, these are the elements allowing to interpret whether a person is blind. They fulfill the role of identification. As a result, the fact of using such helpful devices may be very often perceived, by the blind themselves, as a stigmatizing one.

It is generally connected with the inability to accept one's visual impairment, whether it was a permanent feature from childhood or acquired later as an adult person. For instance, the white cane, one of the things allowing blind people to move independently and safely, is perceived by a lot of them as stigmatizing, which causes reluctance to using it. It is proved both by orientation instructors' experience and statements provided by the blind (Freeman 1993; Witek 2010). On one hand, they acknowledge these aids as negatively distinguishing them, and on the other hand as proving their status of a blind person.

Recent ethnographical studies have also provided interesting information concerning the use of new technologies which help decipher printed texts by the blind. A proper equipment delivered to a blind person facilitates communication, acquiring information, knowledge and spending spare time (by reading digital books, using the Internet). These studies also present that not only the technologi$\mathrm{cal}$ advance and affordable price are crucial premises (although the second factor may very often strongly influence a decision of a purchase) but also social factors (the use of such thing should be as inconspicuous as possible, people do not want to stand out), as well as the ability to perform many other activities without other people's assistance. This, according to a group of questioned people, guarantees efficient integration with the sphere of the sighted and families (Shinohara, Teneberg 2009; Chan, Foss, Poisner 2009; Söderström, Ytterhus 2010).

"Stigma and burden are, next to 'dependence', crucial dimension of the identification of person with disabilities in their and other people's eyes" claims Andrzej Radziewicz-Winnicki (2009, p. 20). It seems that, in case of the blind, the category of stigma happens to be a very vital component of their auto-perception. The researcher also indicates another, recently significant, aspect of stigma in relation to people with disabilities - that sigma is connected with their social position (Radziewicz-Winnicki 2009, p. 20). This aspect of handicaps' stigma is secondary and related to social results of perceiving disability. What goes hand in hand with it is taking roots by adverse social conditions, such as the access to education, work, goods, services and culture. The centre of gravity, in this case, is shifted from attribute, feature, characteristic (understood not only as visible physical otherness but also the difference in functioning, which point is rarely mentioned by social psychologist in relation to the stigma of the blind) to the gradually proceeding, through ages, effect of devaluation. 
Between these poles of the blind's stigma (and disabled people's one), the dynamical changes are being made. Piotr Świtaj notices that the Polish language mentions more often stigmatizing and not stigma. The social process is emphasized, not only the actual feature, characteristic (Świtaj 2005, p. 137). According to Erving Goffman, operating with the category of stigma is concentrated too strongly on attitudes of an individual of a group, whereas the significant role in the comprehension of the phenomenon of social stigmatizing is played by the correlation between attribute, feature and stereotype - the simplified vision of community regardless of their own merits. Goffman emphasizes that stereotype is the essence of a stigma and he suggests the necessity of updating stereotypical beliefs, after having examined people affected by a feature perceived as a stigma (Goffman 2005, p. 33; Czykwin 2008, p. 35).

\section{Stigma or a stereotype of a blind person?}

Directing the public attention towards the phenomenon of stereotype and the process of stereotyping the blind people is crucial for two reasons. First of all, because of the before mentioned correlation between stigma and stereotype. Secondly, due to the existing negation of the usefulness of the concept of stigma in relation to people with disabilities, including the blind. Michael Oliver questions the functionality of stigma, underlining that this category is not becoming the basis for developing strategies helping partially-disabled people in their future. It happens because stigma relates to micro-level of social contacts, certain individual relations, not to the macro-level of excluding disabled people from society and economical sphere (Czykwin 2007, p. 68; Oliver 1990).

The categories of stigma and stereotype, as well as the process resulting from it, are closely related but not identical. Their relations are presented differently. In some cases, stereotyping is the wider and more general process than stigmatizing (Biernat, Dovidio 2008, p. 95). The other approaches interlink stereotyping with stigmatizing. Link and Phelan, for instance, present stigmatizing as multi-stage process (establishing the kind of power of one group over the other) which components are: labelling, stereotyping, separation and the loss of social status, as well as discrimination (Link, Phelan 2001, p. 363-385).

Stereotyping is two-dimensional: it may depend on transforming certain occurrence into the stereotypical situation (e.g. linking certain categories, attributes with already existing stereotypes) or creating a new stereotype. Stereotype is described as the cognitive representation of social groups or, rarely, individuals. It is characterized by the excessive simplification of contents, strongly influential characteristic and significant generalization of a given group's members - in spite of their individual differences or slight susceptibility to changes of stereotypes (Weigl 2000, p. 205-206). 
Pointing out the correlation between stereotype and stigma, Monica Biernat and John N. Dovidio underline that stereotypes are connected with stigmatizing, in the way that the reaction of stigmatizing people is not just negative (reluctance or devaluation of identity) but this reaction implies that stigmatized people are having certain set of features in possession - that with some kind of stigma, a person holds a certain social identity either (2008, p. 96).

These researchers also present two kinds of direction between these phenomenal from stigma to stereotype and from stereotype to stigma.

Stigma, the visible feature causing a pejorative social reaction, may provoke the tendency to associate a whole group of alleged features and crediting them to a particular group. Therefore, it may be the mechanism of the process of stereotyping. In this case, when stigma concerns a characteristic physical or social attribute, then this feature may serve as stimulus activating social categorizing and stereotyping. That, later on, may become culturally accepted and passed on (Biernat, Dovidio 2008, p. 95-97). Jones claims that there can be a strong tendency towards shifting the stigmatizing reactions in the direction of stereotypes, which will justifying or explain these negative emotions. It concerns both racial stereotypes and these explaining the reluctance towards handicapped people (Jones 1984, p. 10).

The other direction of the relation: from stereotype to stigma, is based on the assumption that the established stereotypes become the points of reference for interpreting information concerning an individual of a certain social group. In this way, the examined feature may turn out to be stigmatizing for some social group according to the established stereotype, whereas for others it would seem neutral (Biernat, Dovidio 2008, p. 103).

In a great number of research studies, there are analyses concerning the subjects of stereotypes and prejudice towards disabled people. Social psychologists indicate that these analyses have a different character than the ones connected with sex, race or religion - they are rare to come across, weaker and far more diverse. They may stem from the natural physiological reactions in the form of emotional stimulation, significant discomfort or fear caused by untypical physical features, body deformations (facial ones, visible blindness) harmful for people with such characteristics (Stangor, Crandall 2008, p. 87). The researchers have also shown that non-verbal behaviours revealed during the contact of the able-bodied with handicapped people can be characterized by the high level of tension and greater interpersonal distance. However, Monica Biernat and John. N. Dovidio notice that various types of physical imperfections, observed in the case of face deformation or blindness, for being more scarce, specific and rare, are to a lesser extent a reason to create images of a certain group based on such features. Noticing a blind person, according to the researchers, rather triggers the belief that he or she cannot see, must be unhappy as a result and thus has a set of certain features. The beliefs concerning these defining features have undoubtedly a negative undertone and a person with such stigma may generally be perceived as the representative of the 
devaluated type. Nevertheless, in case of more individual types of stigma, clear and equally acknowledged ones are rare (Biernat, Dovidio 2008, p. 97).

Furthermore, the attitude of the persons without disabilities towards people with disabilities is complex. It may be ambivalent, since next to cognitive negative emotions there are people intellectually aware of existing norms, which direct them to show compassion or assistance. However, there are general reactions (e.g. aversion and sympathy) and not reactions mirroring the impact of commonly held view on the set of beliefs concerning some group, that means the impact of stereotypes (Biernat, Dovidio 2008, p. 111-112).

In spite of these assertions presented in the field literature, we can find numerous analyses functioning in social awareness of patterns of perceiving disabled people as totality. It functions also in relation to individual types of disabilities, including blindness.

The apparent contradiction has its solution. In most research studies conducted by social psychologists, the visible stigma of disability has been analyzed (noticing physical otherness) as the source of stereotype, not the peculiarity of cognitive estimation present in lives of the blind - the consequence of the visual impairment and not adapted physical environment. In the face of previously mentioned statement, the position of Kornelia Czerwińska seems to be adequate. She concludes the work resulting in number of studies on stereotypes and prejudice towards the blind and claims that a lot of attention is drawn to the content of stereotypes, while the origin, level of universality, as well as immutability and accuracy are far less explored and examined (Czerwińska 2007, p. 16).

\section{The content of a blind person's stereotype}

The knowledge of possibilities and actual situation of the blind is extremely important in the case of forming proper relations between all the members of society and neutralizing the existing barriers in work and social spheres for visually impaired people.

Blind people indicate to certain attitude presented towards them or incomprehension of the sighted as being a result of ignorance or, very often, a lack of imagination expressed in:

- the belief that a blind person is capable of doing very little on their own and needs assistance, e.g. in a work place;

- the inadequate image of the blind and treating them as immature or mentally challenged people;

- unjustified fears (e.g. whether one can cope with household responsibilities or safely use a gas stove);

- the incompetent help (pushing instead of being a guide, providing inexact pieces of information and warning, such as "look out" which do not result in enough guidance needed in certain threats); 
- unawareness, when a certain case of disability is not visible, which leads to pejorative remarks and names addressed to the blind;

- thoughtlessness (e.g. rearranging pieces of equipment without providing the blind with precise hints or using visual materials during certain training without further comments);

- unhealthy curiosity, being a form of a test for a blind person to see whether one can manage a given task;

- a deliberate malice;

- refusal of rights accessible for the able-bodied (e.g. marriages, having children) (Życzyńska-Ciołek 2008, p. 272-273).

It is possible to make the assumption that some of these false beliefs and negative actions are a result of stereotypes towards the blind present in social awareness.

In relation to the blind there is a stereotype picturing them as weak, fearful, nervous and lonely people. They are also claimed to be withdrawn, insecure, unhappy and poor (Ostrowska 1994). The stereotype of a blind person reconstructed in literature includes such additional features as helplessness, dependence from others, submission, as well as melancholy, Not rare are: immersion in thoughts, mysteriousness, passivity or low self-esteem, aesthetics, particular sensitivity and ability to foresee future events (Sadowska 2005, p. 40; Czerwińska 2009, p. 94; Czerwińska 2011, p. 45). However, experiencing the lack of ability to see is identified with the full darkness. The blind are claimed to possess special musical, ideal sense of hearing and extraordinary touch (Gorajewska 2006, p. 48-49).

Nevertheless, obviously, a typical blind person with a common for the whole population set of features and personality type does not exist. Better hearing and touch abilities are the result of constant exercising the existing senses during the course of learning the reality. Hence, their use, in comparison to people without disabilities, is more effective (Nazarko 2001; Sękowski 1994; Gorajewska 2006).

\section{Mass media broadcast}

Reinforcing stereotypes and false beliefs concerning visually impaired people is done on several levels, also through mass media broadcast.

The researchers working on analyses of the image of the blind presented in media underline two tendencies. First of them is the presentation of a disabled person as depending on others, needing assistance and evoking mercy. The other of them is picturing a person with disabilities as a hero overcoming every restraint and achieving impressive goals, difficult to make even by the people without disfunction (Barnes 1997).

In Polish reality, interesting facts are provided by Elżbieta Łobacz who analyses the image of the blind in press between years 1996-2000 and 2001-2005. The researches have shown that people with visual impairment were always presented through the prism of their disabilities. Information about their impairment was 
provided at first, followed by descriptions of their skills, problems or special features. There has been a growing tendency to overestimate everyday life activities present in lives of the blind, for whom these seemed natural. Such image, according to the author of the research, is not positive, because it draws attention to problems and difficulties experienced by people with visual impairment. However, she indicates that in the second cycle of researched articles, the image of the blind was more realistic. More aspects concerning possible changes of the reality have occurred; both the sighted and people with visual disabilities were presented as active and willing to overcome existing barriers (Łobacz 2006).

Film broadcast in relation to the blind was examined by Maria Szulc (2001). She took into account feature-length motion pictures with blind characters in plots, possible to watch on Polish TV channels between years 1990 and 2000 . The aspects of presenting their mobility were examined. The analyzed material shows that orientation and mobility are not shown realistically. Visually impaired people are pictured there as depending on counting steps or creating steps maps. What is more, after they have lost their sight they seem to have no problem in orientation around their houses. The presented techniques of mobility with a guide person or a white cane bear a lot of mistakes. The use of a white cane by those characters is attributive. It is, in most of the cases, too short and the grip of a hand is wrong, as well as arcs are too narrow to assure security or to provide necessary information about certain area or place. The most realistic image of a blind person was noticeable when using, by a film character, a help of a guide dog, which was shown as a symbol of a blind person. Sometimes it triggered negative attitude and sometimes was a sign of the self-reliance, independence and freedom from a white cane.

The important field of building the social image of the blind are also visual materials created by institutions working in aid of the disabled people and organizing various social campaigns. It turns out that sometimes, having the best interest in heart, while fighting for the positive image of the blind, the truth about their actual abilities is being falsified (Czerwińska 2007).

In an attempt to break media patterns concerning the blind (presented both as depending on help from others and as people achieving extraordinary goals, as well as the excessive concentration of the attention on features or showing ordinary situations as significant and extraordinary) Polski Związek Niewidomych (Polish Association of the Blind People) creates textual materials such as leaflets and handbooks or materials inaudio-visual form. Their aim is to present an actual situation of the blind and their functioning, as well as the correction of commonly made mistakes in relation to visually impaired people. An interesting example is a guide, in the form of an animated film, showing both a prism of a sighted person and a blind one: ,"N jak Niewidomy, czyli jak pomóc osobie z dyskunkcją wzroku." ("B. as in Blind person - how to help a visually impaired person"). The attention has been drawn to such issues: 
- The negative practice of imposing help on blind people without asking them for permission and the kind the help wanted (pushing, pulling in order to cross the road faster or get off a bus) or creating certain situations by the sighted, when such help is inevitable.

- Techniques and forms of support. The arrangement of a proper hold and right position of a guide next to a blind person (by having a touch contact: is it by lending a hand or elbow by the guide and being a step ahead of a blind person). Help while entering a pedestrian crossing, at the bus stop, on public transport. Also help while locating a place to sit, when going through the door or going down the stairs.

- The character of functioning of each blind person and their differences (recognizing audio hints, peculiarity of writing and reading the spot alphabet).

- Self-reliance of a blind person (strategies of coping with everyday life situations: labelling the surroundings in Braille, using voice computers and audiobooks. Other ways dealing with money, meals and medicines).

- The importance of providing the blind with the right pieces of information (instead of "look out - stairs", there should be: "Look out - stairs to go down/ up").

- Using, in casual communication, phrases connected with seeing sense, such as: "see you", "look at this", "what is your point of view?" as natural statements both for the sighted and visually impaired people.

In previously discussed material, the most common beliefs concerning the blind and claimed by the sighted were confronted with the knowledge of their functions, presenting the blind's feelings in certain situations and referring to imagination of the sighted (using the passage: "please just imagine..."). Because of the belief that lack of some information concerning the blind can be completed with a natural thought or imagination of the sighted.

In the material, the attempt to make the image of the blind to appear as realistic is visible, referring both to their abilities and difficulties or restraints. The self-reliance of blind people and their independence were emphasized. Still acknowledging also certain situations when the help from a sighted person is needed showing the right attitude while talking to a blind person: "You are entirely independent", "You do not need my assistance, sir!" by the sighted after having presented the ways of coping with everyday life situations. But also statements like: "It's not easy", "It cannot be that easy at first" delivered by the interlocutor indicating the areas where assistance is required.

\section{The opposing tendencies to stigmatizing and stereotyping the blind}

Numerous attempts are recently being made to change the negative situation of the blind and to modify their social perception. These concern: 
- Shaping proper attitudes, among other things, by organizing social campaigns and projects addressed to the blind and the sighted, which partially have been shown above in the text.

- Strengthening the independence and self-reliance of the blind by creating orientation courses, which teach safe and independent mobility or refer to everyday life situations connected with new technologies designed to help.

- The actions to even out educational and work chances, by broadening the knowledge of the functioning of the blind. Creating the right conditions for blind people to function, e.g. in an office.

- Expending the access to culture and art for blind people (screening and TV shows, as well as theatre plays with audio-description. What is more, touch representations of some work of art and audio-handbooks).

- Changes in public places by adjusting them to the needs of the blind.

A greater activity of blind people to satisfy their needs can also be observed nowadays. The number of projects are being organized by certain institutions and associations. They are created both by the visually impaired and the sighted. They concentrate on help provided in areas of work, education and culture.

Visible are also slow social changes, for example in Poland recently:

- The concessions for public transport have been raised;

- The duty to broadcast $10 \%$ of the programs as accessible for people with visual impairments (provided with audio-description, subtitles or translated by using sign language);

- The Braille overlay for the ballot paper was introduced during the last general elections.

Although these mentioned changes are positive, they are still showing the alarming image - where the fact that the blind are able to execute their rights to participate in social life is actually a prolonged process, demanding complex and voluntary actions and becomes a privilege, instead of being the owned right.

\section{Language as a social storage of myths and stereotypes. The linguistic component in the image of visually impaired people (in common speech and scholarly discourse)}

Despite initiatives leading to overcome restraints from the full participation of the blind in social, work and cultural life, also by taking into consideration the attitudes and prejudice towards them, one area of devaluation still remains: language. Fixed vocabulary and phraseology reflecting certain types of attitudes, comprehension and opinion. The reality is perceived by us in such prescribed sets of words and is not empirical. It's an echo coming from the society. A man, more often than not, is not able to argue them. This kind of mimesis, consisting of involuntary repetition of speech phrases, leads to the comprehension of the world through language and existing evaluations ( $\mathrm{Nycz}$ 2000, p. 107). The language turns out 
to be a social-dialect, "the storage of social myths" (Riffaterre 1984, p. 142), which receive their representation in fixed phrases or stereotypical networks of metonimy circulating around a certain lexical centre.

The linguistic component in the image of handicapped people was analyzed by Danuta Gorajewska, who browsed through Polish dictionary entries of proverbs and sayings referring to various types of disabilities, also connected with sight (Gorajewska 2006, p. 31-48). The researcher gives over 40 examples of proverbs and phrases referring to the subject of blindness or eye and all of them hold negative attitude. Among them, there were: (translated literally form Polish) "even a blind person may sometimes succeed", "do not ask a blind for help and a fool for advice", "for a blind one eye is enough" or "for a blind each path is winding". Also in English such pattern is visible, for instance in saying" "the blind leading the blind". Gorajewska concludes, basing on these analyses that in social awareness, throughout centuries, there has been an image of the blind as helpless and depending on others and whose only experience is darkness (Gorajewska 2006, p. 46).

Speech canons referring to a disability in the common language are seldom perceived as harmful. As a result, there are no restrictions on repeating them and fixing further beliefs, which base on ignorance concerning the variety of needs and abilities existing in the inhomogeneous community of visually impaired people.

Specific examples being fixed by the language create negative perception of the blind and allow a neglect when it comes to building linguistic phrases. This process can be also analyzed through the prism of an exercise designed for a handbook for integrated education. This exercise was placed under the text about a blind girl, and it was analyzed by Sławomira Sadowska (2005). The aim of this orthographic task was to practice how to write the Polish particle "no" with other speech parts and the material was a set of vocabulary presented in 3 groups. All the words referred to the text and were supposed to create 3 different sentences. There were altogether 12 terms and 6 referring to a girl: "she did not look", "she cannot see", "shy", "inattentive", "ungainly", "hesitantly". While inserting such exercise it must have been ignored that exposing such features, in relation to the blind may result in the belief and opinion that a blind person is worse and weaker (Sadowska 2005, p. 175).

The other aspect of the issue concerning the devaluation of certain disabilities by the language is scholarly discourse. The subject of linguistic categories used to present issues connected with them is described by Zenon Gajdzica (2009). He takes into consideration the consequences of the choice of certain lexis and its effects on later social perception of the handicapped persons. He also indicates reasons for such uses. Giving examples of categories used in the description of the social situation of the handicapped, he notices that majority of them are pejorative while describing individuals, features and situation of people living with disabilities. However, the proportion is different while describing attitudes, social affairs or social organization, which categories seem to be more neutral. In descriptions aiming to specify ways of helping or affecting people with disabilities, 
there are numbers of positive categories. However, among negative categories used for describing the organization of social life of the disabled Gajdzica enumerates: powerlessness, helplessness, immobility, inefficiency, handicap, suffering, dysfunctions, deviation, impotence, passivity, devaluation, extermination, exploitation, violence, trouble, pressure, stigma, addiction, outdistance, marginalization, distance, asymmetry, isolation, exclusion, segregation, cultural imperialism, enslavement. The researcher claims that the result of the use of these phrases or categories is creating certain situations, certain characteristics and stigmatizing them emotionally. Specified images concerning handicapped people are created (Gajdzica 2009, p. 29-31). Indicating the scholarly validity to use negative categories, as describing the reality, and focusing on difficulties and restraints, the researcher points out the social issue of building beliefs about ineptitude as being characteristic for the whole group of handicapped people. It creates a type of thinking which can result in stigmatization or marginalization. In this case, he suggests the use of tensions in description between what is negative and positive, by using, for instance, contrasting categories (Gajdzica 2009, p. 26-29).

The private statement which corresponds to this scholarly analysis was delivered by a person with a visual impairment and referred to the reading of an academic handbook describing psychological functioning of the visually impaired people. The expression of views was in a form of a bitter reflection. After having read that reading the person had a feeling of imposition of negative features, such as low self-esteem, restraints in cognitive sphere and auto-perception stating "deviation from the norm". Whereas, this person's actual perception (due to the declared level) did not held such characteristics. Subjective beliefs and feelings of the individual cannot be a basis for generalization but the person mentions the importance of linguistic forms as building tools for others' perception. This includes blind people and their own perception, as well as social one.

\section{Young learners' perception of visually impaired people. The role of course-books}

Shaping the perception of the blind by other members of society and contact with them, as well as its modification starts from the very young age. It is present in the domestic environment, through conversation and examples given by adults, as well as in the institutional sphere (kindergarten, school) through interpersonal contacts, teachers' statements and proper course-books. Shaping children's perception concerning handicapped people is vital in their early school years and throughout the whole time spent at school. Children create patterns of relations with peers, possible to use as an example for future interactions with handicapped people (Marzec 2002, p. 66).

According to results of researches made by Kornelia Czerwińska, conducted in a group consisting of 136 young learners, and referring to the issue of perceiving 
the blind by them, the stereotypes of features and actions belonging to blind people were also shared by the examined group. The tools in that research was the questionnaire consisting of nine unfinished statements requiring filling in the endings. In most of the filled blanks there were negative opinions attributed to blind people. Among them, there were: poverty, sadness, weakness or unhappiness. The typical perception turned out to be that a blind person depends on and need help. The statements revealed poor or unreliable knowledge concerning the functioning of the blind, their needs and abilities. What is more, it proved the negative consequences deriving from lack of proper school lectures about certain types of disabilities (Czerwińska 2011, p. 46-54).

The important channel of providing information and presenting types of interaction between different members of society involve: texts, graphic representations and examples of tasks present in course-books and school readings. Dorota KlusStańska indicates that "the aim of using readings while teaching young learners ought to be, among others, to enable a young reader to recognize social situations and gain competence to question such readings. [...] It may be done by a child's active building, in contact with the properly chosen piece of literature, of the world's psychological meanings, as well as political and social ones and so on" (Klus-Stańska 2009, p. 26).

Sławomira Sadowska conducted researches concerning the set of 26 coursebooks for grades from 1 to 3 referring to the issue of presenting disabled people in literature, course-books' tasks and in various types of illustrations. There were 12 texts involving the presence of handicapped people (10 of which were literary). Six of them concerned the subject of visually impaired people, five of them referred to motion disabilities and one to hearing ones.

The researcher noticed that literary texts are based on the pattern of the loneliness/helplessness of a child with disabilities, their social contacts and comprehension of their situation. The image of the blind is far more fixed than the one referring to motion disabilities. However, it is usually stereotypical. In spite of revealing individual features concerning these blind characters described in texts, they are preceded by the stereotypical characteristics or even unrealistic image, for instance, by connecting the visual impairment with having musical skills or crediting the blind with abilities to recognize colors by using touch. A template approach towards a blind person happens to be presented also in the pictures, in which the blind are depicted bearing 3 attributes: a white cane, a guide dog and dark glasses.

While analyzing literary texts involving blind characters in the context of a storyline, Sławomira Sadowska noticed that with a subject of a blind child there are connected certain centers of concepts, depending on the moment of interaction of a blind person with their sighted peers. In the part of the text preceding the interaction of such characters these centers are connected with: the kind of impairment (with judgmental opinion: "he is blind" or evaluative-expressional ones: "ha can't see a thing", "poor thing" in relation to visual impairment), when connected 
with movement (description of a pejorative kind) and peculiarity in cognition of the world (limiting information to the tactile writing). In the part of the text following the interaction of the peers, these centers refer to: cognition of the world (the importance of the touch sphere), merits/abilities (there the stereotype of the musical gift may be found), intensive positive emotions provoked by the contact of able-bodied peers with the visually impaired ones. Such semantic concentrations are included in stereotypical way of perceiving the blind. They do not allow to break patterns and sometimes even strengthen them by emphasizing differences between people with and without disabilities, ignoring the things which are in common (Sadowska 2005, p. 168-199). These texts do sensitize to perceive certain troubles blind people may have, but in a pushy way which can become a ritual and serve not as social adjustment but as creating narrow room for manoeuver in the field of mutual contact (Radziewicz-Winnicki 2009, p. 15).

The work with the literary text, on the subject of preparing a child to coexist with other persons perceived as different, was analyzed by Marzena Nowicka. She examined 70 types of studies of literary texts, done by young learners' teachers, as being propositions for work during school classes. The texts chosen by the examined persons, were not presenting richness of social diversity but they were picturing mostly disabled children (majority of them visually impaired). They were shown in the nostalgic atmosphere and tranquility, not in diverse situations. Very often such images involved: loneliness but also family understanding and their support. Their important characteristic was the desire for contacts with healthy peers. In interactions with peers the moment when they stopped behaving improperly towards the ones with visual impairment was emphasized. The feeling of mercy and sympathy were usually accompanying them. Negative emotions and reactions were transformed into full social acceptation of the disabled people. The researcher indicates the fact that in the suggested texts emotional perplexities and ways how to cope with them were not mentioned. It may be dangerous if they happen to a reader and one will not find them in the given model. "A child who experiences them does not know that they are not the only one to feel so, but the lack of them in reading examples tells them to react with a negation or blame the others for such emotions - in this case handicapped people." (Nowicka 2004, p. 49). Nowicka also points out the fact that such readings do not present characters' dilemmas and they idealize interactions between peers. "Models of behaviours are placed in a dynamic social reality full of tensions, but they become distant and not possible to be used in life." (Nowicka 2004, p. 53).

The presented image of the handicapped characters, including visually impaired ones, involved the expectancy of help and showing gratitude, which can strengthen opinion about the superiority of the helping person over the one who is being helped (Nowicka 2004, p. 50). At the same time, the issue of validity of such help was not taken up. In addition, the description of a situation or tact was not mentioned. In the examined text the belief that a handicapped person should be satisfied with 
small gestures was emphasized. The happiness of people with visual impairments is different, based on element which would not satisfy an able-bodied ones.

From these analyses derives the fact that the image of a blind person presented in course-books is stereotypical. It is also strengthening the permanent placement of social roles, in which a person with disability is a receiver of help and people without disability are always delivering it. Also the contents are alarming, as well as the fact that existing beliefs are not ever being broken or questioned by teachers while designing their didactic work. There must be actions taken, such as:

- revision of course-books for their texts concerning the subject of disabilities, and supplementing them with such if necessary, because a lack of them works as masking the reality. But also the elimination of stereotypical texts holding false information ought to be done. Very crucial uis also the suggested work with such text;

- in practice, while working with children, basing on the texts about certain disabilities, instructions must be transformed/changed. The escape from homogenous rules to present proper rules should be developed. Moreover, the reality without emotional perplexity ought not to exist anymore;

- modification of the fixed representations of visually impaired people (e.g. triads: a blind person with a white cane, a guide dog and dark glasses);

- practical realization of assumptions presented in core syllabuses referring to shaping of the abilities of making contacts with children, adults, handicapped people or representatives of other races and maintaining them.

\section{From pedagogic practice}

In order to shape attitudes towards visually impaired people the proper transfer of information about their functioning is required. However, what is noticed by Sławomira Sadowska is that this is not the only strategy needed, because too excessive attention is drawn to differences excluding common grounds (2005, p. 130). The situation where persons without disability will interact with disabled ones, also visually, as fellow-participants in ordinary conversations. Therefore, the visible differences will not be the only characteristics.

The important shift visible in the way of shaping attitudes towards disabled people, including visually impaired ones, particularly among young children, will be the placement of attention to acquiring social skills and presentation of the multi-dimensional reality, where the issue of existence of different people is natural, including the ones with significant differences. The practical way of acting in this field may be creating various syllabuses involving interpersonal tasks which may be used in relation to the whole school-class community, consisting of both students without disability and disabled disciples. The other ways - creating didactic materials presenting the diversity of society and treating all of their members equally, as every component is natural and ordinary. 
In relation to these forms of acting, interesting may be the syllabus created and being tested in Sweden. It is based on publication “Kroppsspråk för alla” („Body language for everybody"). It may become an inspiration to create further syllabuses adjusted to educational systems present in various countries and referring to different kinds of disabilities. "Kroppsspråk för alla" whose authors are Tina Björk and Agneta Croneld is a syllabus treating the development of interpersonal skills and non-verbal communication during drama classes. They came into being while the authors worked in a primary school with integration units, and were conducted and tested there. The book consists of descriptions and presentations of practical ways of conducting such drama classes in big groups (creating staging, acting out the roles, creating mini-musicals. Important are also improvisation and dancing). Among these basic elements of drama exercises, additional tasks, being crucial for shaping interpersonal relations between able-bodied and handicapped students, were involved. There are various exercises meant for practice: interpersonal skills, expressing one's emotions, using gestures and para-language. The authors designed a lot of elements in relation to the blind and visually impaired people, drawing attention to non-verbal communication and difficulties of people with certain visual impairment. Important factors were also mutual and effective communication within mixed groups of students. However, this plan, having been designed for such groups, can also be successful in homogenous groups of handicapped persons.

Visual impairment makes it fully impossible or significantly challenges acquiring information about gestures and attitudes present in verbal communication. The consequence is that a lot of blind people rarely use any gestures or exclude them. The other part being a result of visual impairment is an inability to answer to a non-verbal statement, a look or a smile. Such situations makeit difficult to have interpersonal communication. "Kroppsspråk för alla" is, therefore, a suggestion of exercises designed to achieve new skills in this field of non-verbal communication. Both for persons with and without disability. An important aim of this syllabus is to develop forms of expression through a prism of abilities of a blind person and not to teach them fixed gestures and attitudes natural for the sighted. Forcing visually impaired people to do so in not involved here. Learning and practice concerning body language strengthens self-esteem and confidence. In the studies conducted by Anna Karin Magnusson we can also learn that drama classes are an efficient way to acquire knowledge in subjects, new for visually impaired people, relating to non-verbal communication. The evaluation of students' acting performance, done during workshops, is perceived as normal and do not evoke a feeling of guilt, because it is referring to the characters they play (Magnusson 2003). In this publication crucial ways of interaction in groups were also described, which ought to help blind people during movement or while verbally describing things which are not within their reach to be visually seen by them.

The syllabus described earlier is an interesting example showing the connection between general aims, vital for a whole community of students and referring 
to interpersonal communication specified by particular needs. In this case these were the ways how visually impaired people function. They were supposed to shape the attitudes of different, in some aspects, groups of people. However, that kind of syllabus for developing non-verbal communication skills was not designed for blind people to learn how to merge into the crowd of the sighted but should be conducted so they can develop their own ways of non-verbal expression. Its merit is the fact that it can be used while working with a group of able-bodied, as well as in a mixed group.

The next particular kind of medium referring to shaping attitudes towards disabled persons, including visually impaired ones, is educational material designed for grades from 1 to 3 of a primary school titled "Razem w szkole podstawowej" ("Together in a primary school") written by Danuta Gorajewska. It supports the syllabus of Stowarzyszenie Przyjaciół Integracji (The Friends of the Integration Association) titled "Czy naprawdę jesteśmy inni? Razem w naszej szkole" (“Are we really different? Together in our school"). The aim of the publication, and of the exercises attached, is broadening the social competence of students and building the proper belief that a disability is an internal element of life - while referring to children's experience, this is also a component of relations present in a classroom. The aims are being achieved by a number of exercises. It is worth mentioning that these tasks are also bearing a lot of cognitive aims. Disabled children, mostly with motion dysfunction, visual or hearing impairments are presented as self-reliable and as independent as it is only possible for them. Various situations where shown when each pupil may need assistance and everyone is able to offer it.

The presented materials, as exemplification of recent proper practice in shaping attitudes towards visually impairment people (and disabled ones in general) ought to become an inspiration to creating further syllabuses and didactic materials possible to use in inclusion education.

\section{Conclusion}

External stigma connected with visual impairment (facial deformations, incorrect posture or motion pattern, blindisms - but not characteristic for all blind people), attributive way of defining this group (a white cane, a guide dog, dark glasses) or peculiarity of orientation-cognitive functioning - these features may evoke certain emotional reaction while first contact of a person with a blind one, and/or by perceived as devaluating such individual. Such a situation may cause the stereotype to happen, reinforce the already existing one or false belief and negative social facts concerning the situation of the blind, such as educational barriers, or access to goods and services. Some others are also difficulties in existing in social life, which can cause strengthening of dependence on others, assigning lower standards. Marginalization can be either the effect of stigmatization and stereotyping, 
or cause a secondary stigma - which is present in low social status of disabled people, including visually impaired ones.

The opposing tendencies to such negative processes consist of many entities and directions. They might be noticed in the actions made by active members of community of visually impaired people. They concern key areas of life, such as: education, work, social roles, access to culture and art, as well as full access to goods and services. An important area of this trend is care for shaping social competences of the youngest members of society, referring also to interaction with visually impaired people and handicapped ones, in general. They are based on proper, these days, pedagogic practice.

While designing support for social adjustment of visually impaired people the existence of informational channels which may have a "hidden curriculum" of devaluation of blind people, such as: common speech, scholarly discourse, coursebooks or mass media should not be forgotten. The results of the researches and analyses of those areas presented in this article and indication of negative facts ought to sensitize one to their importance, as they are only outwardly marginal because of being placed next to the most vital pro-integral actions, but they hold crucial sense for them to be successful.

\section{References}

Bachtin M. (1986). Problem gatunków mowy. In: M. Bachtin, Estetyka twórczości słownej. Warszawa: PIW.

Barnes C. (2008). Niepetnosprawność. Warszawa: Sic!

Barnes C. (1997). Wizerunki niepełnosprawności i media: badanie sposobów przedstawiania osób niepetnosprawnych w środkach masowego przekazu. Lublin: Print 6.

Biernat M., Dovidio J. N. (2008). Piętno i stereotypy. In: T. F. Heatherton, R. E. Kleck, M.R. Hebl, J. G. Hull (ed.), Społeczna psychologia piętna. Warszawa: Wyd. Naukowe PWN, Collegium Civitas.

Björk T., Croneld A. (2010). Kroppsspråk för alla. Umeå: Ordalaget Bokförlag, Specialpedagogiska skolmyndigheten.

Chan S., Foss B., Poisner D. (2009). Assistive Technology for Reading. "Intel" Technology Journal", 3 .

Czerwińska K. (2011). Obraz osób niewidomych w opiniach dzieci w wieku wczesnoszkolnym - komunikat z badań. „Niepełnosprawność i Rehabilitacja”, 1.

Czerwińska K. (2009). Kondycja i wyzwania współczesnej tyflopedagogiki. In: G. Dryżałowska, H. Żuraw (ed.), Trwałość i zmiana w pedagogice specjalnej. Warszawa: Żak.

Czerwińska K. (2007). Stereotypy i uprzedzenia wobec osób niewidomych i słabo widzacych - przeglad badań. „Wychowanie na co dzień”, 7/8.

Czykwin E. (2007). Stygmat społeczny. Warszawa: Wyd. Naukowe PWN. 
Erenc J. (2008). Bycie innym. Problem wykluczenia i izolacji ludzi niepełnosprawnych. Gdańsk: Wyd. UG.

Ferenc K. (2008). Źródła kształtowania się postaw wobec osób niepetnosprawnych. In: G. Miłkowska, B. Olszak-Krzyżanowska (ed.), Teraźniejszość i przyszłość osób niepełnosprawnych $w$ kontekście społecznych zmian. Kraków: Impuls.

Fine M., Asch A. (1988). Disability beyond Stigma: Social Interaction, Discrimination, and Activism. "Journal of Social Issues", vol. 44, 1.

Freeman M. (1993). On the stigma of blindness. In: Making Hay, K. Jernigan (ed.). National Federation of the Blind.

Gajdzica Z. (2009). Kategorie opresyjne i nacechowane pozytywnie $w$ deskrypcji sytuacji społecznej człowieka niepelnosprawnego. In: Z. Gajdzica (ed.), Człowiek $z$ niepetnosprawnościa w przestrzeni społecznej. Kraków: Impuls.

Goffman E. (2005). Piętno: rozważania o zranionej tożsamości. Gdańsk: GWP.

Goffman E. (1963). Stigma: Notes on the Management of Spoiled Identity. New York: Prentice Hall.

Gorajewska D. (2006). Fakty i mity o osobach z niepetnosprawnością. Warszawa: Stowarzyszenie Przyjaciół Integracji.

Gorajewska D. (2010). Razem w szkole. Warszawa: Stowarzyszenie Przyjaciół Integracji.

Jones E.E., Scott R. A., Markus H. (1984). Social, Social Stigma: The Psychology of Marked Relationships. New York: W.H. Freeman.

Kawczyńska-Reguła B., Pierzchała B. (2001). Zagadnienia nauczania poczatkowego dzieci $z$ dysfunkcja wzroku. In: S. Jakubowski (ed.), Poradnik dydaktyczny dla nauczycieli realizujacych podstawe programowa w zakresie szkoły podstawowej i gimnazjum z uczniami niewidomymi i słabo widzacymi. Warszawa: MEN.

Klimasiński K. (1987). Postawy widzacych wobec niewidomych. „Przegląd Tyflologiczny", 1-2.

Klus-Stańska D. (2009). Od niechęci wobec dziecięcej samodzielności myślenia do przekazu fikcji społecznej. „Studia Pedagogiczne Uniwersytetu HumanistycznoPrzyrodniczego Jana Kochanowskiego", t. 18. Kielce.

Link BG, Phelan J.C. (2001). Conceptualizing stigma. „Annual Review of Sociology”, 27.

Łobacz E. (2006). Prezentacja osób niewidomych w prasie. „Szkoła Specjalna”, 4. Magnusson A. K. (2008). The Body Language of Adults Who Are Blind. "Scandinavian Journal of Disability Research", 2.

Marchwicka M., Durka G. (1995). Zachowania i dystans społeczny wobec osób $z$ widocznym inwalidztwem wzroku na podstawie opinii dorosłych mieszkańców Stupska. „Przegląd Tyflologiczny”, 1-2.

Marszałek L. (2007). Społeczny kontekst niepełnosprawności. „Seminare”, 24.

Marzec E. (2002). Modyfikacja postaw wobec osób $z$ dysfunkcja wzroku. In: L. Frąckiewicz (ed.), Postawy wobec niepełnosprawności. Katowice: Wyd. Uczelniane AE. 
Menec V. H., Perry R. P. (1998). Reactions to Stigmas Among Canadian Students: Testing an Attribution-Affect-Help Judgment Model. "Journal of Social Psychology", 138.

Nazarko G. (2001). Muzyka. In: S. Jakubowski (ed.), Poradnik dydaktyczny dla nauczycieli realizujacych podstawe programowa w zakresie szkoły podstawowej i gimnazjum z uczniami niewidomymi i słabo widzacymi. Warszawa: MEN.

Niemiec M. (2009). Funkcjonowanie społeczne młodzieży niepetnosprawnej wzrokowo. In: A. Klinik (ed.), Edukacja jako proces socjalizacji osób niepetnosprawnych. Kraków: Impuls.

Nowak A. (2005). Marginalizacja osób niepetnosprawnych. In: A. Nowak (ed.), Wybrane społeczno-socjalne aspekty marginalizacji. Katowice: ŚWSzZ im gen. J. Ziętka.

Nowicka M. (2004). Praca z tekstem literackim dla dzieci - szansa czy przeszkoda w edukacji do innego. In: D. Klus-Stańska (ed.), Światy dziecięcych znaczeń. Warszawa: „Żak”.

Nycz R. (2000). Tekstowy świat. Kraków: Universitas.

Oliver M. (1990). The Politics of Disablement: A Sociological Approach. New York: St. Martins Press.

Ostrowska A. (1994). Niepełnosprawni w społeczeństwie. Postawy społeczeństwa polskiego wobec ludzi niepetnosprawnych (raport z badań). Warszawa.

Owens J. (2009). The Influence of 'Access' on Social Exclusion and Social Connectedness for People with Disabilities. In: A. Taket, B.R. Crisp, A. Nevill, G. Lamaro, M. Graham, S. Barter-Godfrey (ed.), Theorising Social Exclusion. London: Routledge.

Pescolido B. A., Martin J. K. (2007). Stigma and the Sociological Enterprise. In: W.R. Avison, J.D. McLeod, B.A. Pescolido (ed.), Mental Health. Social Mirror. Sprniger US.

Radziewicz-Winnicki A. (2009). "Piętno” jako traumatyczny stan doznawanego upośledzenia społecznego. In: Z Gajdzica (ed.), Człowiek z niepelnosprawnościa w przestrzeni społecznej. Kraków: Impuls.

Radziewicz-Winnicki, A., Radziewicz-Winnicki, I. (2005). Pojęcie marginalizacji wykluczenia w naukach społecznych. In: A. Nowak (ed.), Wybrane społeczno-socjalne aspekty marginalizacji. Katowice: ŚWSzZ im gen. J. Ziętka.

Riffaterre M. (1984). Intertextual Representation. "Critical Inquiry", 1.

Rush L.L (1998). Affective Reactions to Multiple Social Stigmas. "The Journal of Social Psychology", 138.

Sadowska S. (2005). Ku edukacji zorientowanej na zmianę społecznego obrazu osób niepetnosprawnych. Toruń: Akapit.

Sahaj T. (2011). Niepetnosprawność i niepetnosprawni w mediach: filmy, seriale, internet. Warszawa: Instytut Rozwoju Służb Społecznych.

Sękowski A. (1994). Psychospołeczne determinanty postaw wobec inwalidów. Lublin: Wyd. UMCS. 
Shinohara K., Tenenberg J. (2009). A Blind Person's Interactions with Technology. "Communications of the ACM", 8.

Söderström S., Ytterhus B. (2010). The use and non-use of assistive technologies from the world of information and communication technology by visually impaired young people: a walk on the tightrope of peer inclusion. "Disability \& Society", 3 . Stangor C., Crandall C.S. (2008). Zagrożenie i społeczna konstrukcja piętna. In: T. F. Heatherton, R. E. Kleck, M. R. Hebl, J. G. Hull, Społeczna psychologia piętna. Warszawa: Wyd. Naukowe PWN, Collegium Civitas.

Szulc M. (2001). Orientacja przestrzenna osób niewidomych przedstawionych $w$ filmach. In: J. Kuczyńska-Kwapisz (ed.), Orientacja przestrzenna w usamodzielnianiu osób niewidomych. Warszawa: Wyd. APS.

Świtaj P. (2005). Piętno choroby psychicznej. „Postępy Psychiatrii i Neurologii”, 14. Walthes R. (2007). Tyflopedagogika. Gdańsk: GWP.

Weigl B. (200o). Stereotypy i uprzedzenia. In: J. Strelau (ed.), Psychologia, t. 3 , Gdańsk: GWP.

Witek B. (2010). W kilku słowach. „Biuletyn Informacyjny Trakt”, 9-10.

Wojciechowski F. (2003). Stereotypy i uprzedzenia a proces normalizacji życia osób z niepełnosprawnością. In: E. Górniewicz, A. Krause (ed.), Dyskursy pedagogiki specjalnej. Konteksty teoretyczne. Olsztyn: Wyd. UWM.

Życzyńska-Ciołek D. (2008). Osoby z deficytami wzroku. In: W. Łukowski (ed.), Osoby z ograniczoną sprawnością na rynku pracy - portret środowiska. Warszawa: Wyd. Academica.

\section{STYGMATYZACJA I STERETYPIZACJA OSÓB NIEWIDOMYCH. TENDENCJE PRZECIWSTAWNE}

Streszczenie: Celem artykułu jest zaprezentowanie aspektów stygmatyzacji i stereotypizacji osób niewidzących w świetle teorii stygmatyzacji Ervinga Goffmana. Omówiono także tendencje przeciwstawne zjawiskom naznaczenia społecznego i tworzenia uproszczonych schematów poznawczych dotyczących tej grupy osób, wśród których należy wymienić rewizję języka potocznego i tekstów kultury w kierunku nieutrwalania zafałszowanego obrazu osób niewidomych. Na koniec przedstawiono także narzędzia i materiały przydatne w pracy pedagogicznej ukierunkowanej na tworzenie środowiska inkluzyjnego.

Słowa kluczowe: niewidzenie, osoba niewidoma, stygmat, stereotyp.

Emilia Śmiechowska-Petrovskij - doktor nauk społecznych w dyscyplinie pedagogika, pedagog specjalny (tyflopedagog) i filolog polski, adiunkt w Katedrze Pedagogiki Specjalnej Przedszkolnej i Wczesnoszkolnej Wydziału Nauk Pedagogicznych Uniwersytetu Kardynała Stefana Wyszyńskiego w Warszawie, ekspert Ośrodka Rozwoju Edukacji ds. weryfikacji podręczników i książek pomocniczych w brajlu i powiększonym druku, rzeczoznawca MEN ds. podręczników dla dzieci o specjalnych potrzebach edukacyjnych. Zainteresowania 
badawcze: wsparcie osób z niepełnosprawnościami, ze szczególnym uwzględnieniem niepełnosprawności wzrokowej, w obszarze edukacji, integracji społecznej i uprzystępniania dóbr kultury. Autorka ponad 30 opracowań naukowych i popularnonaukowych z obszaru tyflopedagogiki. Pozycje książkowe: Książki literackie dla niewidomych dzieci w młodszym wieku szkolnym. Perspektywa dorosłych pośredników (2017), K. Krawiecka, E. Śmiechowska-Petrovskij, M. Żelazkowska, Sztuka/twórczość dostępna. Osoby z niepełnosprawnościami i choroba psychiczna w kręgu recepcji i ekspresji sztuki (2016), redaktorka i współredaktorka książek: Dzieci z trudnościami adaptacyjnymi w młodszym wieku. Aspekty rozwojowe i edukacyjne w kontekście specyfiki różnic kulturowych (2016), Selected Aspects of Psychosocial Functioning of Persons with Disabilities (2016), K. Krawiecka, E. Śmiechowska-Petrovskij, Ż. Tempczyk-Nagórka (red.). Adres do korespondencji: Wydział Nauk Pedagogicznych, ul. Wóycickiego 1/3, 01-938 Warszawa. Adres e-mail: e.smiechowska@uksw.edu.pl 